\title{
Lidar detection of high concentrations of ozone and aerosol transported from northeastern Asia over Saga, Japan
}

\author{
Osamu Uchino ${ }^{1,2}$, Tetsu Sakai ${ }^{2}$, Toshiharu Izumi ${ }^{2}$, Tomohiro Nagai $^{2}$, Isamu Morino ${ }^{1}$, Akihiro Yamazaki ${ }^{2}$, \\ Makoto Deushi $^{3}$, Keiya Yumimoto ${ }^{2}$, Takashi Maki ${ }^{2}$, Taichu Y. Tanaka ${ }^{2}$, Taiga Akaho ${ }^{4}$, Hiroshi Okumura $^{4}$, \\ Kohei Arai ${ }^{4}$, Takahiro Nakatsuru ${ }^{1}$, Tsuneo Matsunaga ${ }^{1}$, and Tatsuya Yokota ${ }^{1}$ \\ ${ }^{1}$ National Institute for Environmental Studies, 16-2 Onogawa, Tsukuba, Ibaraki 305-8506, Japan \\ ${ }^{2}$ Meteorological Research Institute, 1-1 Nagamine, Tsukuba, Ibaraki 305-0052, Japan \\ ${ }^{3}$ Japan Meteorological Agency, 1-3-4 Otemachi, Chiyoda-ku, Tokyo 100-8122, Japan \\ ${ }^{4}$ Saga University, 1 Honjo-machi, Saga, Saga 840-8502, Japan \\ Correspondence to: Osamu Uchino (uchino.osamu@nies.go.jp)
}

Received: 16 June 2016 - Discussion started: 22 June 2016

Revised: 28 December 2016 - Accepted: 7 January 2017 - Published: 8 February 2017

\begin{abstract}
To validate products of the Greenhouse gases Observing SATellite (GOSAT), we observed vertical profiles of aerosols, thin cirrus clouds, and tropospheric ozone with a mobile-lidar system that consisted of a two-wavelength (532 and $1064 \mathrm{~nm}$ ) polarization lidar and a tropospheric ozone differential absorption lidar (DIAL). We used these lidars to make continuous measurements over Saga $\left(33.24^{\circ} \mathrm{N}\right.$, $130.29^{\circ}$ E) during 20-31 March 2015. High ozone and high aerosol concentrations were observed almost simultaneously in the altitude range $0.5-1.5 \mathrm{~km}$ from 03:00 to 20:00 Japan Standard Time (JST) on 22 March 2015. The maximum ozone volume mixing ratio was $\sim 110 \mathrm{ppbv}$. The maxima of the aerosol extinction coefficient and optical depth at $532 \mathrm{~nm}$ were $1.2 \mathrm{~km}^{-1}$ and 2.1 , respectively. Backward trajectory analysis and the simulations by the Model of Aerosol Species IN the Global AtmospheRe (MASINGAR) mk-2 and the Meteorological Research Institute Chemistry-Climate Model, version 2 (MRI-CCM2), indicated that mineral dust particles from the Gobi Desert and an air mass with high ozone and aerosol (mainly sulfate) concentrations that originated from the North China Plain could have been transported over the measurement site within about 2 days. These high ozone and aerosol concentrations impacted surface air quality substantially in the afternoon of 22 March 2015. After some modifications of its physical and chemical parameters, MRI-CCM2 approximately reproduced the high ozone volume mixing ratio. MASINGAR mk-2 successfully predicted high aerosol
\end{abstract}

concentrations, but the predicted peak aerosol optical thickness was about one-third of the observed value.

\section{Introduction}

Tropospheric ozone is a major air pollutant and impacts human health and vegetation (HTAP, 2010; Yue and Unger, 2014). It is also an important greenhouse gas (IPCC, 2013). Tropospheric aerosols are also air pollutants and aggravate respiratory conditions (HTAP, 2010). Tropospheric aerosols also enhance radiative forcing in a negative (sulfuric acid particles) or positive (black carbon) way (IPCC, 2013), and they affect remote sensing, for example the measurement of greenhouse gases from space (Houweling et al., 2005; Uchino et al., 2012a). It is therefore very important to monitor tropospheric ozone and aerosols and to understand their temporal and spatial variations. On the one hand, aerosols transported from East Asia to western Japan have been observed by lidar, and their vertical distributions have been reported (Iwasaka et al., 1988: Murayama et al., 2001; Hara et al., 2009). On the other hand, ozone from Asia has been studied mainly via surface measurements (Akimoto et al., 1996; Yamaji et al., 2006). Continuous ozone vertical distributions measured by differential absorption lidar (DIAL) are very useful for studying transport processes and the origin of the ozone. 
To validate products of the Greenhouse gases Observing SATellite (GOSAT), we developed a two-wavelength (532 and $1064 \mathrm{~nm}$ ) polarization lidar (hereafter referred to as Mie lidar) to observe vertical profiles of tropospheric and stratospheric aerosols and thin cirrus clouds at the National Institute for Environmental Studies (NIES), Tsukuba $\left(36.05^{\circ} \mathrm{N}\right.$, $140.13^{\circ} \mathrm{E}$ ), Japan, in 2009. In 2010 we also developed a DIAL to measure tropospheric ozone profiles (hereafter abbreviated as ozone DIAL). The ozone DIAL was installed in a container with the Mie lidar. In March 2011, we moved the lidar container to Saga $\left(33.24^{\circ} \mathrm{N}, 130.29^{\circ} \mathrm{E}\right)$ in the Kyushu district of western Japan at a location $2.6 \mathrm{~m}$ above sea level. The ozone DIAL was modified in September 2012 (Uchino et al., 2014).

Mie lidar has been used to demonstrate the influence of high-altitude aerosols and cirrus clouds on the GOSAT product of the column-averaged dry air mole fraction of carbon dioxide $\left(\mathrm{XCO}_{2}\right)$ retrieved from the Thermal And Near infrared Sensor for carbon Observation-Fourier Transform Spectrometer (TANSO-FTS) short-wavelength infrared (SWIR) spectral data onboard GOSAT. The $\mathrm{XCO}_{2}$ data were improved by taking the vertical profiles of aerosols and cirrus clouds measured by Mie lidar into account (Uchino et al., 2012a). The increases in stratospheric aerosols caused by the 2009 Sarychev eruption and the 2011 Nabro eruption were observed by Mie lidar (Uchino et al., 2012b).

Ozone DIAL has been used to validate the GOSAT ozone product retrieved from TANSO-FTS thermal infrared (TIR) spectral data (Ohyama et al., 2012), to observe ozone concentrations in the lower troposphere, and to compare the observed concentrations with those predicted by the Meteorological Research Institute Chemistry-Climate Model, version 2 (MRI-CCM2) (Deushi and Shibata, 2011). Use of Mie lidar and ozone DIAL will facilitate satellite product validation not only for GOSAT but also for upcoming satellites such as the TROPOspheric Monitoring Instrument (TROPOMI; Veefkind et al., 2012) and the Geostationary Environment Monitoring Spectrometer (GEMS; Bak et al., 2013). Highozone episodes in the lower troposphere have been observed by lidar (Banta et al., 1998; Koutidis et al., 2002; Ancellet and Ravetta, 2005; Eisele and Trickl, 2005; Kuang et al., 2011). Those observational records were limited to at most 1 week. We made an 11-day continuous record during 2031 March 2015.

In this paper we report an event during which high concentrations of ozone and aerosols were observed almost simultaneously below an altitude of $1.5 \mathrm{~km}$ over Saga on 22 March 2015 by Mie lidar and ozone DIAL. That event substantially impacted surface air quality. We also compared the observational results with those simulated by the models.
Table 1. Characteristics of Mie lidar.

\begin{tabular}{|c|c|c|}
\hline \multicolumn{3}{|l|}{ Transmitter } \\
\hline Laser & \multicolumn{2}{|c|}{ Nd:YAG } \\
\hline Wavelength & $532 \mathrm{~nm}$ & $1064 \mathrm{~nm}$ \\
\hline Pulse energy & $130 \mathrm{~mJ}$ & $130 \mathrm{~mJ}$ \\
\hline Pulse repetition rate & \multicolumn{2}{|c|}{$10 \mathrm{~Hz}$} \\
\hline Pulse width & \multicolumn{2}{|c|}{$8 \mathrm{~ns}$} \\
\hline Beam divergence & $0.2 \mathrm{mrad}$ & $0.2 \mathrm{mrad}$ \\
\hline Receiver & \\
\hline Telescope type & \multicolumn{2}{|c|}{ Schmidt-Cassegrain } \\
\hline Telescope diameter & \multicolumn{2}{|c|}{$30.5 \mathrm{~cm}$} \\
\hline Focal length & \multicolumn{2}{|c|}{$3048 \mathrm{~mm}$} \\
\hline Field of view & \multicolumn{2}{|c|}{$1 \mathrm{mrad}$} \\
\hline Polarization & $P$ and $S$ & none \\
\hline Number of channels & 3 & 1 \\
\hline \multicolumn{3}{|l|}{ Interference filter } \\
\hline Center wavelength & $532.0 \mathrm{~nm}$ & $1064.1 \mathrm{~nm}$ \\
\hline Bandwidth (FWHM) & $0.29 \mathrm{~nm}$ & $0.38 \mathrm{~nm}$ \\
\hline Transmission & 0.66 & 0.58 \\
\hline \multirow[t]{2}{*}{ Detectors } & PMT & APD \\
\hline & (Hamamatsu R3234-01) & (EG\&G C30956EH) \\
\hline Signal processing & \multicolumn{2}{|c|}{12 bit $\mathrm{A} / \mathrm{D}+$ photon counting } \\
\hline Time resolution & \multicolumn{2}{|l|}{$1 \min$} \\
\hline Vertical resolution & \multicolumn{2}{|l|}{$7.5 \mathrm{~m}$} \\
\hline
\end{tabular}

\section{Characteristics of the lidar system and observed parameters}

Mie lidar and ozone DIAL were installed in a container with dimensions of about $228 \mathrm{~cm}$ (width) by $683 \mathrm{~cm}$ (length) by $255 \mathrm{~cm}$ (height), as shown in Fig. 1. Mie lidar is a twowavelength (532 and $1064 \mathrm{~nm}$ ) polarization lidar based on a neodymium-doped yttrium-aluminum-garnet (Nd:YAG) laser; the characteristics are summarized in Table 1 . The output energy at 532 and $1064 \mathrm{~nm}$ was $130 \mathrm{~mJ}$, with a pulse repetition rate of $10 \mathrm{~Hz}$. The diameter of the receiving telescope was $30.5 \mathrm{~cm}$. The output signals from the photomultiplier tubes (PMT) and a silicon avalanche photodiode (APD) were processed by transient recorders with a 12 bit analog to digital converter and a photon counter.

The data analysis methods of Mie lidar and ozone DIAL have been described by Uchino et al. (2012b) and Uchino et al. (2014), respectively. We summarize the observation parameters obtained by Mie lidar. The backscattering ratio $R$ is defined as

$R=(\mathrm{BR}+\mathrm{BA}) / \mathrm{BR}$,

where BR and BA are the Rayleigh and Mie backscattering coefficients, respectively. Backscattering ratio profiles were derived by the inversion method (Fernald, 1984). The reference altitude was usually set between 9 and $12 \mathrm{~km}$, where only molecular backscattering could be assumed in the absence of clouds. We assumed the lidar ratio LR (extinctionto-backscatter ratio) for aerosols to be $50 \mathrm{sr}$ at $532 \mathrm{~nm}$ and $45 \mathrm{sr}$ at $1064 \mathrm{~nm}$ based on the lidar ratios for Asian dust and pollutant aerosols summarized by Sakai et al. (2003), Ander- 

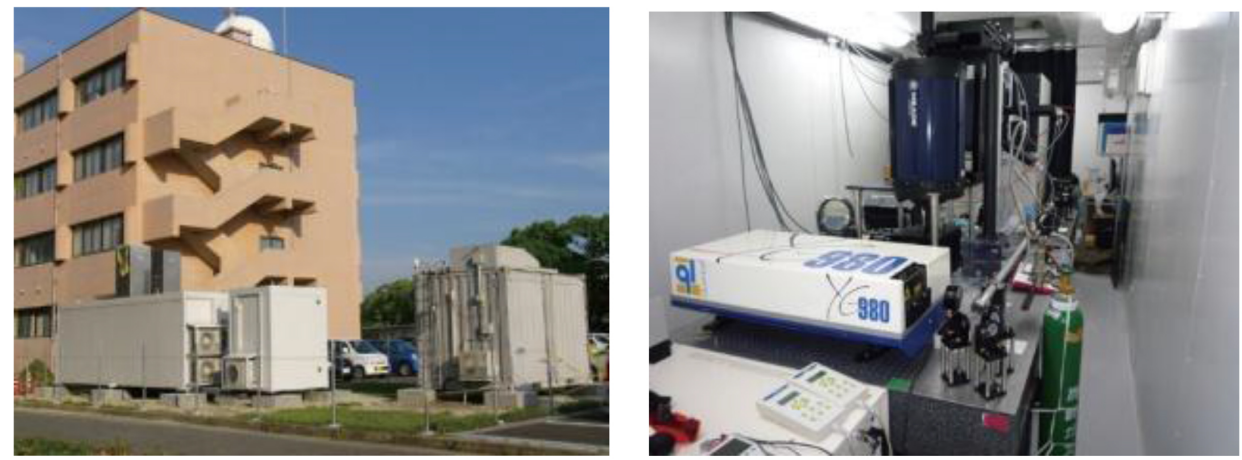

Figure 1. The Mie lidar and ozone DIAL (right picture) were installed in the container at the left on the ground (left picture).

son et al. (2003), and Cattrall et al. (2005). The following is a summary of their lidar ratios at $532 \mathrm{~nm}$ :

- Asian dust $47 \pm 18$ sr (Sakai et al., 2003);

- dust (spheroids) $42 \pm 4 \mathrm{sr}$, southeastern Asia pollution $58 \pm 10 \mathrm{sr}$ (Cattral et al., 2005);

- Aerosol Characterization Experiment (ACE) -Asia pollution (fine-dominated, submicron portion) $50 \pm 5 \mathrm{sr}$, dust (coarse-dominated, dust-like chemistry, supermicron portion) $46 \pm 8 \mathrm{sr}$ (Anderson et al., 2003).

As a simplification, we used the same value for both Asian dust and pollutant aerosols. To calculate BR, we used the atmospheric molecular density profiles obtained by operational radiosondes at the Fukuoka District Meteorological Observatory $\left(33.58^{\circ} \mathrm{N}, 130.38^{\circ} \mathrm{E}\right)$, Japan Meteorological Agency (JMA). The aerosol extinction coefficient was calculated by multiplying BA by LR.

The total volume depolarization ratio $D$ was defined as

$D=S /(P+S) \times 100(\%)$,

where $P$ and $S$ are the parallel and perpendicular components of the backscattered signals, respectively. The particle depolarization ratio $D_{\mathrm{p}}$ was obtained from the equation

$D_{\mathrm{p}}=\left(D \times R-D_{\mathrm{m}}\right) /(R-1)$,

where $D_{\mathrm{m}}$ is the atmospheric molecular depolarization ratio. We used a $D_{\mathrm{m}}$ value of $0.37 \%$ for this lidar system; we calculated $D_{\mathrm{m}}$ from the spectral transmission data of the interference filter at $532 \mathrm{~nm}$ and the Rayleigh backscattering cross sections (Sakai et al., 2003). The value of $D_{\mathrm{p}}$ indicates whether the particles are spherical or non-spherical; large values indicate the presence of non-spherical particles. The backscatter-related Ångström exponent, Alp, the qualitative indicator of aerosol particle size, is defined by

$\mathrm{BA}(\lambda) \propto \lambda^{-\mathrm{Alp}}$, where $\lambda$ is the wavelength. Larger values of Alp indicate the predominance of smaller (i.e., submicrometer-sized) particles. The vertical resolution of these observational parameters was $150 \mathrm{~m}$, and the time resolution was set to be $1 \mathrm{~h}$ for comparison with the Model of Aerosol Species in the Global Atmosphere (MASINGAR)-mk2 (Yukimoto et al., 2012). The lowest altitude of Mie lidar measurement was $225 \mathrm{~m}$ due to the imperfect overlap of the transmitter-receiver optical axes of the lidar system.

The ozone DIAL consisted of a Nd:YAG laser and a $2 \mathrm{~m}$ long Raman cell filled with $\mathrm{CO}_{2}$ gas that generated four Stokes lines from stimulated Raman scattering by $\mathrm{CO}_{2}$; the characteristics are summarized in Table 2 . In this study, we used three Stokes lines (276, 287, and $299 \mathrm{~nm}$ ). The output energies of these Stokes lines were about 8-9 mJ per pulse, with a pulse repetition rate of $10 \mathrm{~Hz}$. The receiving telescope diameters were $10 \mathrm{~cm}$ for boundary layer ozone measurements and $49 \mathrm{~cm}$ for free-tropospheric-ozone measurements. The Mie lidar and ozone DIAL were synchronized by two pulse-delay generators.

The $276 / 287 \mathrm{~nm}$ and $287 / 299 \mathrm{~nm}$ wavelength pairs were used for ozone DIAL measurements in the altitude ranges $0.57-2.0$ and $2.0-6.0 \mathrm{~km}$, respectively. The effective vertical resolutions were $270 \mathrm{~m}$ for $0.57-2.0 \mathrm{~km}$ and $540 \mathrm{~m}$ for 2.0 $6.0 \mathrm{~km}$, respectively (Uchino et al., 2014). The time resolution was set to $1 \mathrm{~h}$ to facilitate comparison with MRI-CCM2. An aerosol correction was not made for ozone retrieval. Next, we report the continuous lidar observational results made at Saga from 20 March to 31 March 2015.

\section{Ozone DIAL data}

Figure 2a shows a time-altitude cross section of ozone volume mixing ratios observed by DIAL at Saga from 11:10 JST on 20 March to 14:33 JST on 31 March 2015. Lidar observations were not obtained from 15:56 JST on 27 March to 21:58 JST on 29 March 2015, mainly because conditions were rainy or cloudy. We made quality checks of the DIAL data. The gray regions in Fig. 2a correspond to ar- 
Table 2. Characteristics of the tropospheric ozone DIAL system.

\begin{tabular}{|c|c|c|c|c|c|}
\hline \multicolumn{6}{|l|}{ Transmitter } \\
\hline Pump laser & \multicolumn{5}{|l|}{ Nd:YAG } \\
\hline Wavelength & \multicolumn{5}{|l|}{$266 \mathrm{~nm}$} \\
\hline Pulse energy & \multicolumn{5}{|l|}{$107 \mathrm{~mJ}$} \\
\hline Pulse repetition rate & \multicolumn{5}{|l|}{$10 \mathrm{~Hz}$} \\
\hline Pulse width & \multicolumn{5}{|l|}{$8 \mathrm{~ns}$} \\
\hline Raman active gas & \multicolumn{5}{|l|}{$\mathrm{CO}_{2}$} \\
\hline Stokes lines & $276 \mathrm{~nm}$ & \multirow{3}{*}{$\begin{array}{l}287 \mathrm{~nm} \\
9.1 \mathrm{~mJ}\end{array}$} & $299 \mathrm{~nm}$ & \multicolumn{2}{|c|}{$312 \mathrm{~nm}$} \\
\hline Pulse energy & $7.5 \mathrm{~mJ}$ & & $8.4 \mathrm{~mJ}$ & Not meas & \\
\hline Beam divergence & \multicolumn{4}{|l|}{$0.1 \mathrm{mrad}$} & \\
\hline \multicolumn{6}{|l|}{ Receiver } \\
\hline Telescope type & \multicolumn{3}{|l|}{ Newtonian } & \multicolumn{2}{|c|}{ prime focus (fiber coupled) } \\
\hline Telescope diameter & \multicolumn{3}{|l|}{$49 \mathrm{~cm}$} & \multicolumn{2}{|c|}{$10 \mathrm{~cm}$} \\
\hline Focal length & \multicolumn{3}{|l|}{$1750 \mathrm{~mm}$} & \multicolumn{2}{|l|}{$320 \mathrm{~mm}$} \\
\hline Field of view & \multicolumn{3}{|l|}{$1 \mathrm{mrad}$} & \multicolumn{2}{|l|}{$3 \mathrm{mrad}$} \\
\hline Interference filter & & & & & \\
\hline Center wavelength & $287.2 \mathrm{~nm}$ & $299.0 \mathrm{~nm}$ & $312.0 \mathrm{~nm}$ & $276.1 \mathrm{~nm}$ & $287.2 \mathrm{~nm}$ \\
\hline Bandwidth (FWHM) & $1.02 \mathrm{~nm}$ & $1.15 \mathrm{~nm}$ & $0.82 \mathrm{~nm}$ & $1.07 \mathrm{~nm}$ & $1.05 \mathrm{~nm}$ \\
\hline Transmission & 0.18 & 0.32 & 0.36 & 0.17 & 0.21 \\
\hline Detectors & \multicolumn{5}{|c|}{ PMT (Hamamatsu R3235-01) } \\
\hline Signal processing & \multicolumn{5}{|c|}{ 12bit A/D + photon counting } \\
\hline Time resolution & \multicolumn{5}{|c|}{$1 \mathrm{~min}$} \\
\hline Vertical resolution & \multicolumn{5}{|l|}{$7.5 \mathrm{~m}$} \\
\hline
\end{tabular}

eas where there were no observational data or the errors were larger than $10 \%$. The errors were computed from the lidar signal-to-noise ratios by use of Poisson statistics. Regions surrounded by a black rectangle are areas where the data were affected by aerosols and/or clouds with $R$ larger than 2 at $299 \mathrm{~nm}$. We calculated $R$ assuming $\mathrm{LR}=50 \mathrm{sr}$, without correcting for attenuation by ozone absorption. In the lowest row of Fig. 2a, we show hourly data of surface oxidant volume mixing ratios $\left(\mathrm{O}_{x}\right)$ at Takagimachi in Saga measured by the Saga Prefectural Environmental Research Center (https://www.pref.saga.lg.jp/web/at-contents/kankyo1/ shisetsu/_40810/_41304/_67819.html). Takagimachi is located about $2.8 \mathrm{~km}$ northeast of the ozone DIAL site. Because the surface $\mathrm{O}_{x}$ was observed by a UV photometer, the contribution of other components such as peroxyacetyl nitrate (PAN) to oxidant concentrations was extremely low, and the oxidant volume mixing ratio was considered to be that of ozone.

Figure $2 \mathrm{a}$ indicates that the ozone volume mixing ratios measured by DIAL were usually about 50-70 ppbv during the study period. Comparatively high ozone concentrations, $>75 \mathrm{ppbv}$, were detected at altitudes of $0.57-3$ and $0.57-2 \mathrm{~km}$ on 20-23 March and 30-31 March, respectively. Notably high ozone volume mixing ratios of $90-110 \mathrm{ppbv}$ at altitudes of $0.57-1.5 \mathrm{~km}$ were observed from $03: 00$ to 20:00 JST on 22 March. These high ozone concentrations were also seen in the surface-photochemical-oxidants data, i.e., the $\mathrm{O}_{x}$ equaled 92-101 ppbv from 15:00 to 21:00 JST on 22 March, as shown in the lowest row in Fig. 2a. The maximum concentration of $\mathrm{O}_{x}$ was $101 \mathrm{ppbv}$ at 16:00 JST. This maximum value was far above the environmental quality standard of $60 \mathrm{ppbv}$ for hourly photochemical oxidants in Japan (https://www.env.go.jp/en/air/aq/aq.html).

\subsection{Comparison of DIAL data with MRI CCM-2}

MRI-CCM2 is a global model that simulates chemical and physical processes that affect the distribution and evolution of ozone and other trace gases from the surface to the stratosphere (Deushi and Shibata, 2011). Uchino et al. (2014) have provided an outline of MRI-CCM2. The vertical resolution of the model increases from about 100 to $600 \mathrm{~m}$ from the surface to $6 \mathrm{~km}$. The time step of the transport (chemistry) scheme is 30 (15) min. We used hourly model output data. The horizontal resolution is about $110 \mathrm{~km}$. We examined whether or not the model could simulate DIAL observational results. MRI-CCM2 simulated the DIAL observations reasonably well. However, MRI-CCM2 predicted high ozone concentrations of 50-60 ppbv and could not reproduce the concentrations of 90-110 ppbv observed with DIAL below an altitude of 1.5 km during 03:00-20:00 JST on 22 March 2015.

We therefore performed some simulations in which we changed the emission inventory data and the term that forced the reanalysis wind field. The most reasonable results, shown in Fig. 2b, were obtained when the following changes were made. The $e$-folding time of the nudging term was changed from 18 to $12 \mathrm{~h}$ to more strongly force the simulated wind 
(a)

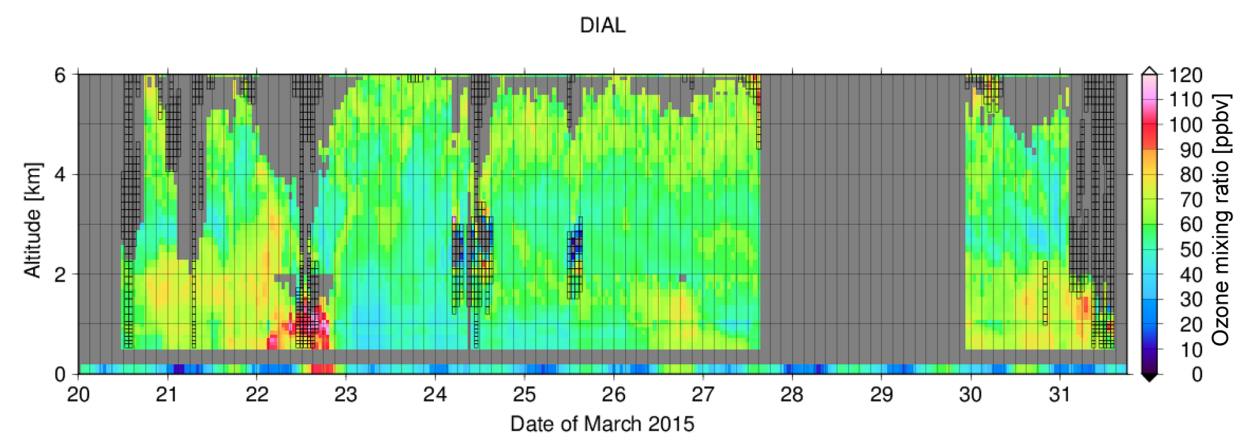

(b)

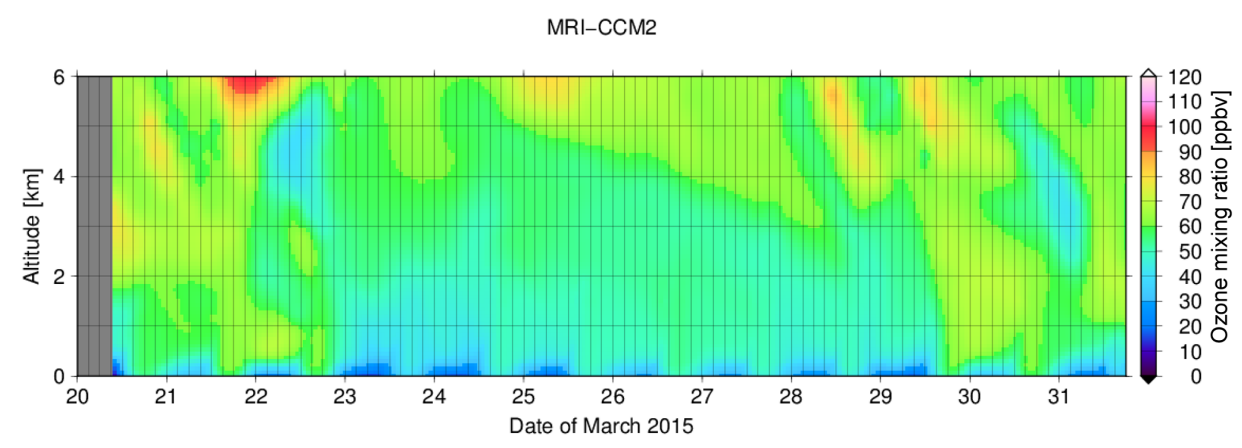

(c)

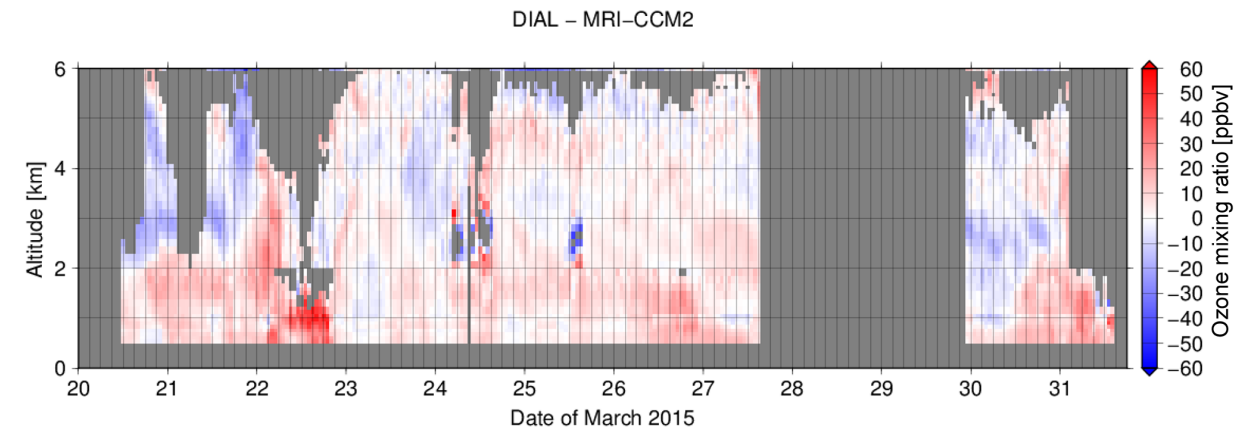

Figure 2. Time-altitude cross sections of (a) ozone volume mixing ratios observed by DIAL over Saga from 11:10 JST on 20 March to 14:33 JST on 31 March 2015, (b) the ratios simulated by a modified MRI-CCM2 for 20-31 March 2015, and (c) the difference between the observed and simulated ozone volume mixing ratios (a-b). Gray regions indicate areas where there were no observational data or the statistical errors were larger than $10 \%$. Regions enclosed with black rectangles are areas where the data were affected by aerosols and/or clouds. The lowest row in (a) shows photochemical oxidant (ozone) volume mixing ratios at Takagimachi in Saga as measured by the Saga Prefectural Environmental Research Center.

fields toward the reanalysis data. In addition, we changed the emission inventory of Regional Emission inventory in Asia version 1.1 (REAS 1.1) (Ohara et al., 2007) to the REAS 2.1 emission inventory in 2007 (Kurokawa et al., 2013) and the $\mathrm{NO}_{2} / \mathrm{NO}_{x}$ emissions ratio from 5 to $15 \%$ by volume, which is within the range of uncertainty (Carslaw, 2005). The emission inventory of $\mathrm{NO}_{x}$ increased about $50 \%$ from REAS 1.1 to REAS 2.1. Figure 2c shows the differences between the observed and simulated ozone-mixing ratios. Simulated ozone volume mixing ratios were about $60-70 \mathrm{ppbv}$ below an altitude of $1.5 \mathrm{~km}$ from 14:00 JST on 21 March to 21:00 JST on 22 March 2015, lower by about 20-50 ppbv compared with the DIAL results. Moreover, MRI-CCM2 predicted high ozone concentrations half a day earlier than the DIAL observations.

The maximum bias (systematic error) of ozone DIAL data caused by aerosols was estimated to be $20 \%$ (15 ppbv) at $0.57 \mathrm{~km}$; the mean bias and its standard deviation were $7 \pm 5 \%$ in the altitude range $0.57-2.0 \mathrm{~km}$ at $11: 00 \mathrm{JST}$. These biases were estimated from Alp observed at the same time 
(a)

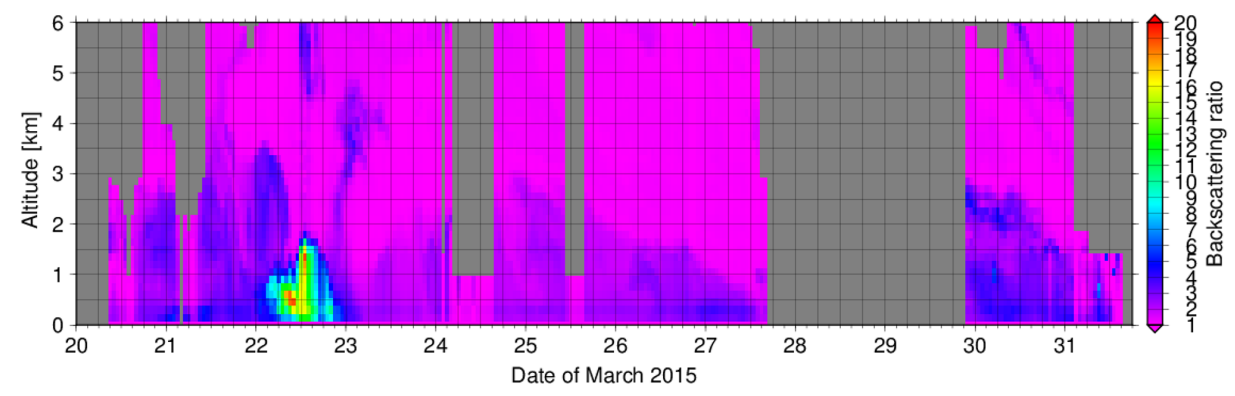

(b)

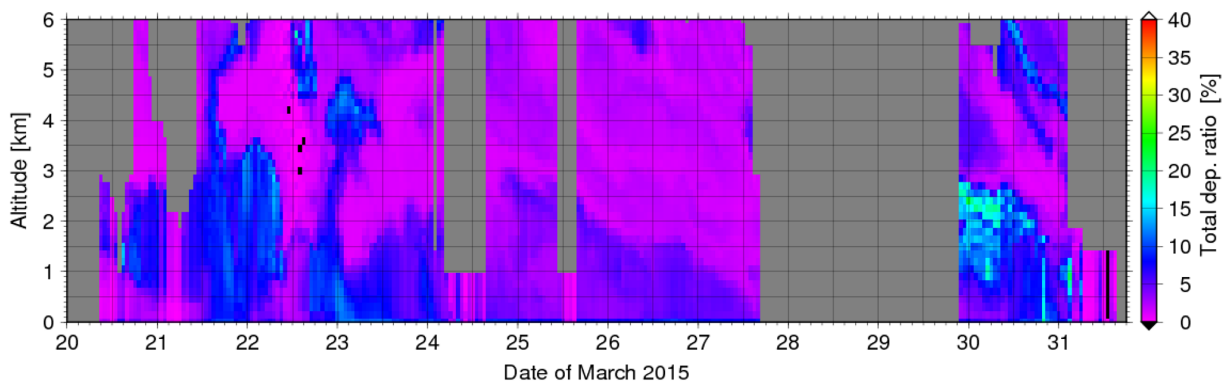

(c)

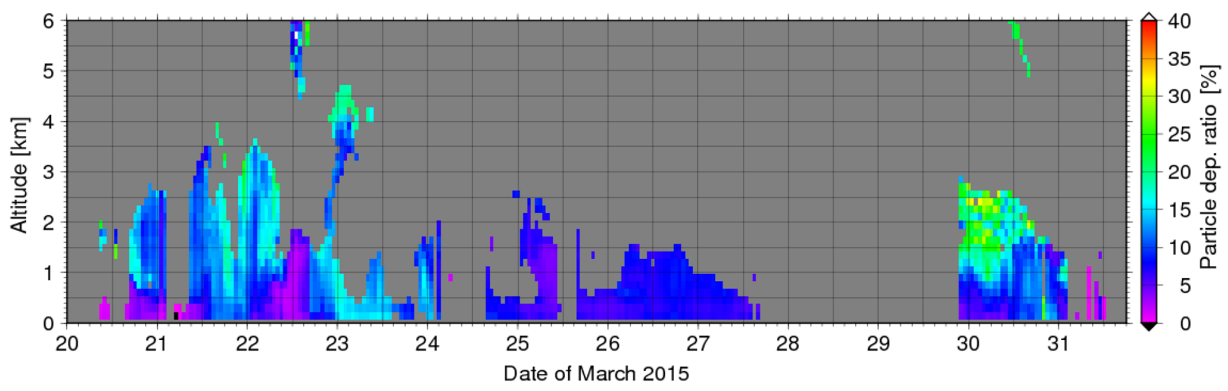

Figure 3. Time-altitude cross sections of (a) backscattering ratios, (b) total volume depolarization ratios, and (c) particle depolarization ratios for $R \geq 2.0$ at $532 \mathrm{~nm}$ observed by Mie lidar at Saga from 09:24 JST on 20 March to 14:34 JST on 31 March 2015. Lidar observations were not available from 15:56 JST on 27 March to 21:58 JST on 29 March 2015 mainly because of rainy or cloudy conditions. Gray regions are areas where there were no observational data or where the observations were affected by clouds.

by Mie lidar and assuming $\mathrm{LR}=50 \mathrm{sr}$ in the wavelength range $276-299 \mathrm{~nm}$ based on Eqs. (6) and (7) in Uchino and Tabata (1991). These biases were not large because the $276 / 287 \mathrm{~nm}$ and $287 / 299 \mathrm{~nm}$ wavelength pairs are suitable for measurements of ozone in the boundary layer and the free troposphere, respectively (Nakazato et al., 2007). As mentioned earlier, ozone DIAL data with a statistical error smaller than $10 \%$ were used in this study. Therefore, the uncertainty in the ozone DIAL data was estimated to be smaller than $22 \%$, and the mean value of the uncertainty was $12 \%$. A model with higher horizontal resolution might be necessary to more realistically simulate high surface ozone concentration events in the planetary boundary layer.

\section{Mie lidar data}

Figure $3 \mathrm{a}, \mathrm{b}$, and $\mathrm{c}$ show time-altitude cross sections of the backscattering ratio $(R)$, the total volume depolarization ratio $(D)$, and the particle depolarization ratio $\left(D_{\mathrm{p}}\right)$, respectively, observed by Mie lidar at Saga from 09:24 JST on 20 March to 14:34 JST on 31 March 2015. Mie lidar data were not obtained from 15:56 JST on 27 March to 21:58 JST 


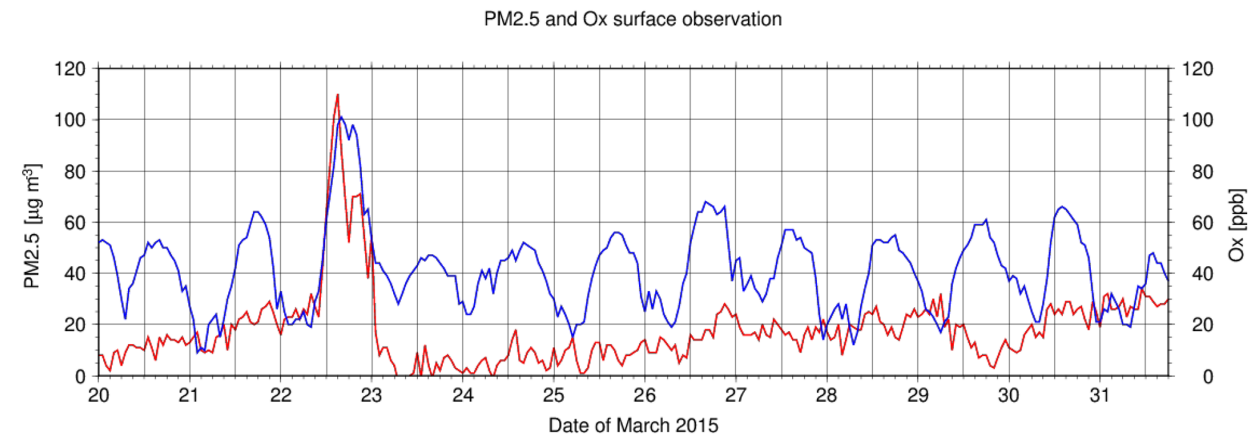

Figure 4. Hourly (JST) data of surface $\mathrm{PM}_{2.5}$ (red line) and $\mathrm{O}_{x}$ (blue line) measured by the Saga Prefectural Environmental Research Center for 20-31 March 2015. The volume mixing ratio of $\mathrm{O}_{x}$ was considered to be that of ozone.

on 29 March 2015, mainly because conditions were rainy or cloudy. We made quality checks of Mie lidar data. Gray regions are areas where there were no observational data or the data were affected by clouds.

Aerosol layers with $R$ in the range 2-4 almost always existed below an altitude of $2.5 \mathrm{~km}$ during 20-31 March 2015 . An event of high aerosol loading with large values of $R$ (> 8) was observed below altitudes of $1.5 \mathrm{~km}$ during 03:0021:00 JST on 22 March, when the values of $D$ were small (the mean \pm standard deviation was $3.9 \pm 2.1 \%$ ) compared with those before and after the event. The values of $D$ were larger than 7.9 $\pm 2.1 \%$ from 15:00 JST on 21 March through 15:00 JST on 23 March, except for 03:00-21:00 JST on 22 March. The main aerosol component during the event might have been submicrometer-sized spherical particles, because $D_{\mathrm{p}}$ was small $(4 \pm 2 \%)$, and the wavelength exponent Alp was large $(1.3 \pm 0.3)$. In contrast, the main aerosol particles before and after the event may have been supermicrometer-sized, nonspherical mineral dust particles because $D_{\mathrm{p}}$ was comparatively large (13 $\left.\pm 3 \%\right)$ and Alp was $1.0 \pm 0.2$ (Sakai et al., 2003; Cattrall et al., 2005). When there were no clouds above, $R$ at $1064 \mathrm{~nm}$ was estimated assuming $\mathrm{Alp}=1.5$ at the reference altitude, where very small amounts of aerosols were expected to be present, i.e., $R=1.06 \pm 0.06(D=1.2 \pm 0.5)$ at $532 \mathrm{~nm}$ in the altitude range 3-6 km. If the value of Alp was changed from 1.0 to 2.0 at the reference altitude, the uncertainty in Alp was estimated to be \pm 0.2 . Alp was $0.3-2.0$ in the 11-day Mie lidar record. The maximum errors of $D$ and $D_{\mathrm{p}}$ were 0.1 and $2 \%$ for $R>2$ at $532 \mathrm{~nm}$.

During the same time period, high aerosol concentrations were also observed at the surface (Fig. 4). Hourly values of the mass concentrations of particulate matter with a diameter of $2.5 \mu \mathrm{m}$ or less $\left(\mathrm{PM}_{2.5}\right)$ at Takagimachi measured by the Saga Prefectural Environmental Research Center were $23 \mu \mathrm{g} \mathrm{m}^{-3}$ at 10:00 JST and increased up to a maximum value of $110 \mu \mathrm{g} \mathrm{m}^{-3}$ at 15:00 JST on $22 \mathrm{March}$; the concentrations were greater than $82 \mu \mathrm{g} \mathrm{m}^{-3}$ during 13:00-16:00 JST and decreased to $17 \mu \mathrm{g} \mathrm{m}^{-3}$ at 01:00 JST on 23 March. The daily mean value of $\mathrm{PM}_{2.5}$ was $50.6 \mu \mathrm{g} \mathrm{m}^{-3}$ for $24 \mathrm{~h}$ on 22 March at Takagimachi, larger than the environmental quality standard of $35 \mu \mathrm{g} \mathrm{m}^{-3}$ in Japan (https://www.env.go. jp/en/air/aq/aq.html).

\subsection{Comparison of Mie lidar data with MASINGAR mk-2}

The MASINGAR-mk2 is an improved version of the MASINGAR aerosol model (Tanaka et al., 2003); it treats five aerosol species: sulfate, black and organic carbon, sea salt, and soil dust. We used emission data for sulfur dioxide and for black and organic carbon from MACCity (Granier et al., 2011). Soil dust and sea salt were represented by 10 bins with particle diameters of $0.2-20 \mu \mathrm{m}$. The model was coupled online with the atmospheric general circulation model MRI-AGCM3 (Yukimoto et al., 2012). The meteorological fields were taken from JMA Global ANALysis data (GANAL). The horizontal resolution of the MASINGAR$\mathrm{mk} 2$ was about $60 \mathrm{~km}$, and the number of vertical layers was 40 from the surface to $0.1 \mathrm{hPa}$. The vertical resolutions increased from 100 to $600 \mathrm{~m}$ from the lowest level to $6 \mathrm{~km}$. The time step of the transport (chemistry) scheme was $450 \mathrm{~s}$, and we used hourly model output data.

Figure 5a and $\mathrm{b}$ show the time-height cross sections of aerosol extinction coefficients observed by Mie lidar and simulated by MASINGAR-mk2, respectively. Figure 5c represents the difference between the observed and simulated extinction coefficients. The model was able to capture the general characteristics of the observational results rather well. A close look at Fig. 5c reveals that the model underestimated the aerosol extinction coefficients of the anthropogenic pollutant event on 22 March but slightly overestimated the extinction coefficients associated with particles having larger total volume depolarization ratios on 30 and 31 March (i.e., dust-dominant case). 
(a)

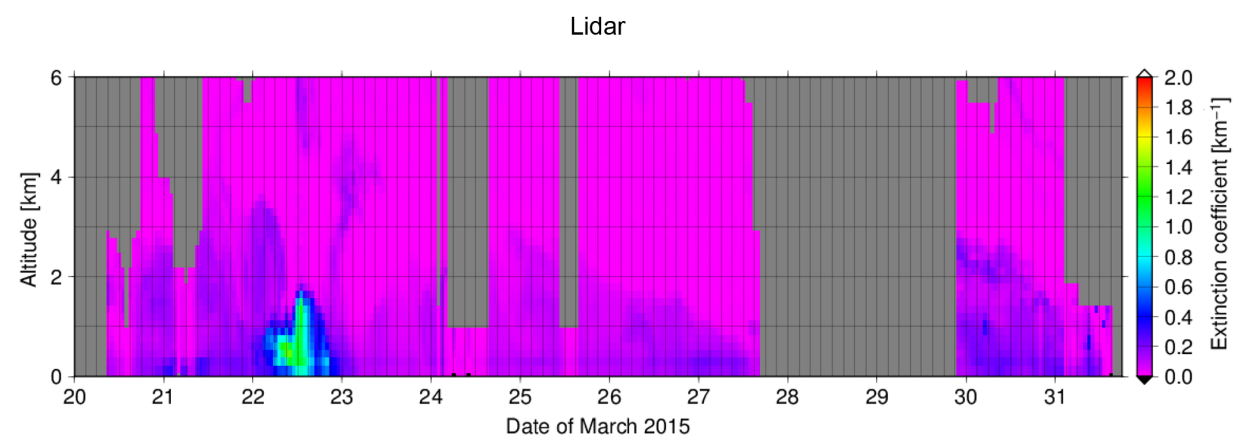

(b)

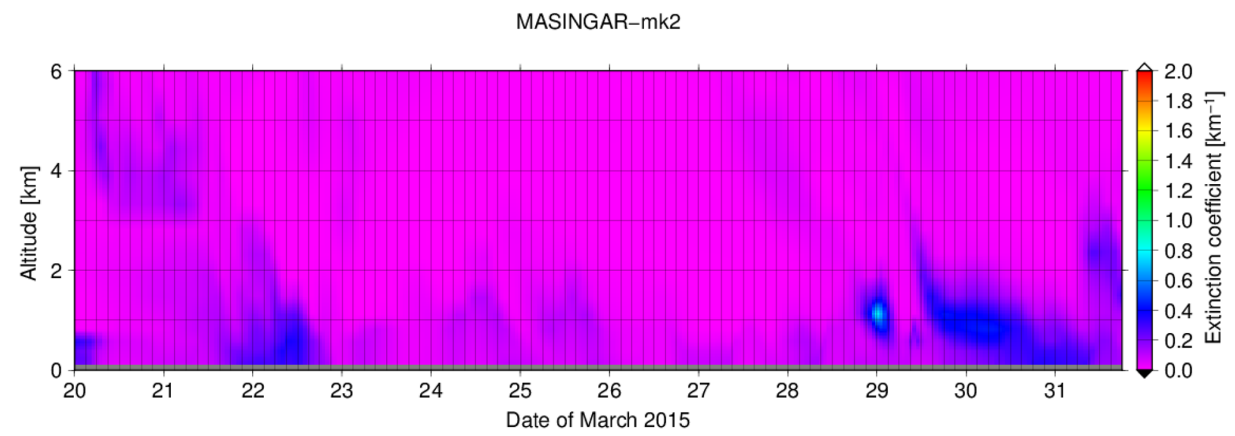

(c)

Lidar - MASINGAR-mk2

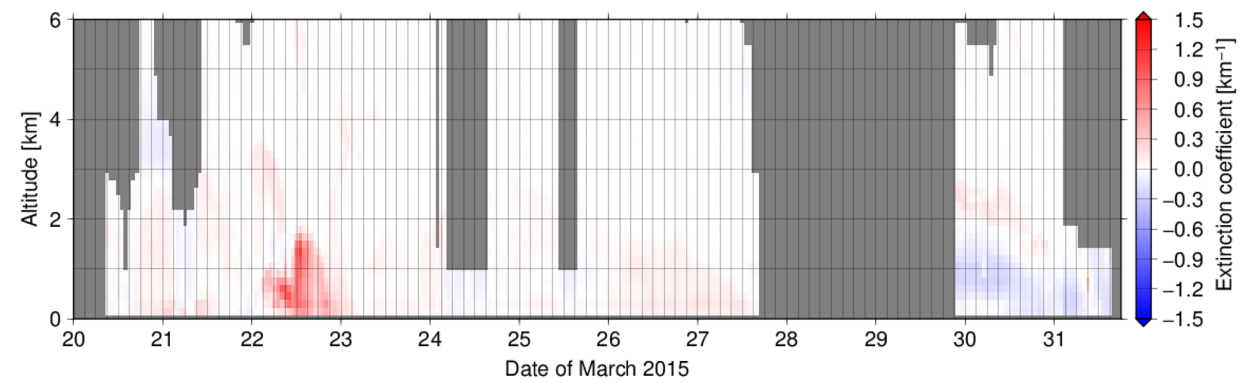

Figure 5. Time-altitude cross sections of (a) aerosol extinction coefficients observed by Mie lidar at 532 nm over Saga from 09:24 JST on 20 March to 14:34 JST on 31 March 2015, (b) the coefficients simulated by MASINGAR-mk2 at 550 nm for 20-31 March 2015, and (c) the difference between the Mie lidar observations and the simulation (a-b). Gray regions represent areas where there were no observational data.

\subsection{Comparison of aerosol optical depths}

Figure 6 shows temporal variations in the aerosol optical depths (AODs) measured by Mie lidar at $532 \mathrm{~nm}$ and sky radiometer at $500 \mathrm{~nm}$ (Kobayashi et al., 2006; Uchino et al., 2012a) and simulated at $550 \mathrm{~nm}$ by MASINGAR-mk2 from 20 to 31 March. To estimate AODs from the lidar data, the extinction coefficient at $225 \mathrm{~m}$ was extrapolated to the ground, the extinction coefficient from 15 to $35 \mathrm{~km}$ was observed at night on the same day, and $S$ was assumed to be $50 \mathrm{sr}$ for all altitudes. When clouds and thick aerosols were present, AODs were not obtained. The sky radiometer was positioned on the roof of the building, which is four sto- ries high and located to the west of the container (brown building in Fig. 1). Although it must be noted that the measured and simulated wavelengths differed slightly, the AODs were almost the same, except for the high-aerosol and ozone event on 22 March. The mean bias \pm the standard deviation of the AOD between Mie lidar and sky radiometer was $0.029 \pm 0.051$, and that between MASINGAR mk-2 and sky radiometer was $-0.07 \pm 0.24$ for 20-31 March, except for 12:00-14:00 JST on 22 March. The maximum values of the AODs were 2.1 at 12:00 JST by lidar, 1.92 at 13:00 JST by sky radiometer, and 0.53 at 13:00 JST by MASINGAR-mk2. One possible reason for the large difference in AOD $(\sim 0.2)$ between Mie lidar and sky radiometer data is that we set the 


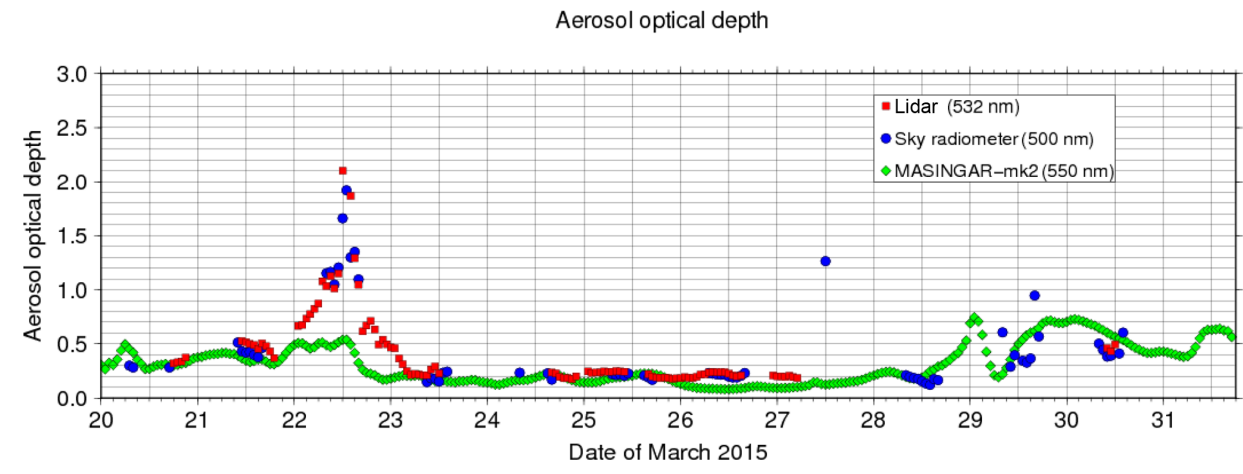

Figure 6. Temporal variation of the aerosol optical depth (AOD) measured by Mie lidar at $532 \mathrm{~nm}$ (red squares) and by sky radiometer at $500 \mathrm{~nm}$ (blue circles), and simulated at $550 \mathrm{~nm}$ by MASINGAR-mk2 (green diamonds).

reference altitudes to 8.2 and $2.8 \mathrm{~km}$ at 12:00 and 13:00 JST on 22 March, respectively, for the lidar because the backscattered signals were strongly attenuated by the dense aerosol layers below $2 \mathrm{~km}$. This might have caused errors in the AODs for the Mie lidar data. The possibility that the views obtained by the sky radiometer and Mie lidar differed might also account for the difference.

The model underestimated the AODs by factors of about 3.6-4 compared to the sky radiometer and lidar observations. One plausible reason for that is that the model resolution (about $60 \mathrm{~km}$ ) was insufficient to reproduce the observed prominent peak in which the observed AOD increased from 1.0 to 2.0 in $6 \mathrm{~h}$. The other plausible reason for the underestimation is the uncertainty of the emissions inventories of aerosol precursors. Grainer et al. (2011) collected various emission inventories and compared them on a global scale. They found that differences in Chinese sulfur dioxide $\left(\mathrm{SO}_{2}\right)$ emissions in 2000 reached $66 \%$ between the lowest and highest emissions and concluded that there was no consensus among the different inventories for the emissions of Chinese $\mathrm{SO}_{2}$. This large variation among the inventories indicates that there is a large error associated with the estimate of $\mathrm{SO}_{2}$ emission in China. In their comparison, the MACCity emission, which was used in the MASINGARmk2 simulation, showed the lowest amount of Chinese $\mathrm{SO}_{2}$ emission among the inventories. This might explain the underestimation of pollutant aerosol (sulfate) concentrations. In the MASINGAR-mk2 simulation, the dust-emission flux was estimated by a parameterized dust emission scheme and was strongly dependent on various parameters (e.g., soil texture, soil wetness, land use, snow cover fraction, vegetation cover, and surface wind speed). The dust model intercomparison project (DMIP; Uno et al., 2006) reported that simulated amounts of dust emissions over East Asia differed sometimes by a factor of 10 among eight dust models (including the previous version of MASINGAR). These facts indicate that estimates of dust emissions are associated with large errors. To solve this problem, for example, it might be better to use the near-real-time-satellite data of $\mathrm{SO}_{2}$ and nitrogen dioxide
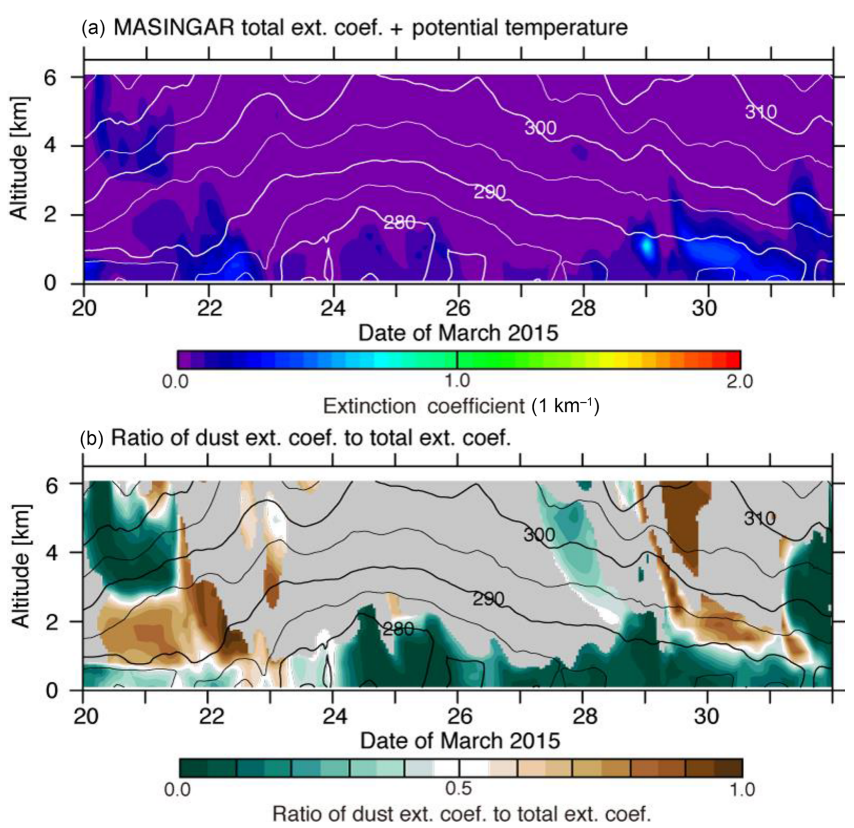

Figure 7. Time (JST)-altitude cross sections of (a) total aerosol extinction coefficients at $550 \mathrm{~nm}$ (color shading) and (b) ratios of dust extinction coefficient to total aerosol extinction coefficient (color shading) simulated by the MASINGAR-mk2 with potential temperatures (white (a) and black (b) contours) over Saga for 2031 March 2015. The gray regions in (b) indicate that the simulated total aerosol extinction coefficient was less than 0.02 .

$\left(\mathrm{NO}_{2}\right)$ provided by the Ozone Monitoring Instrument (OMI) onboard NASA's Aura satellite (Krotkov et al., 2016), and/or to use a data assimilation technique that integrates model simulation and observational data (Yumimoto et al., 2016).

\section{Discussion: origin and transport pathways of ozone and aerosol plumes}

Figure 7 shows the time-altitude cross sections of total aerosol extinction coefficients at $550 \mathrm{~nm}$, and the ratios of 
(a) NOAA HYSPLIT MODEL
Backward trajectory ending at 21:00 UTC 21 Mar 15
GDAS meteorological data

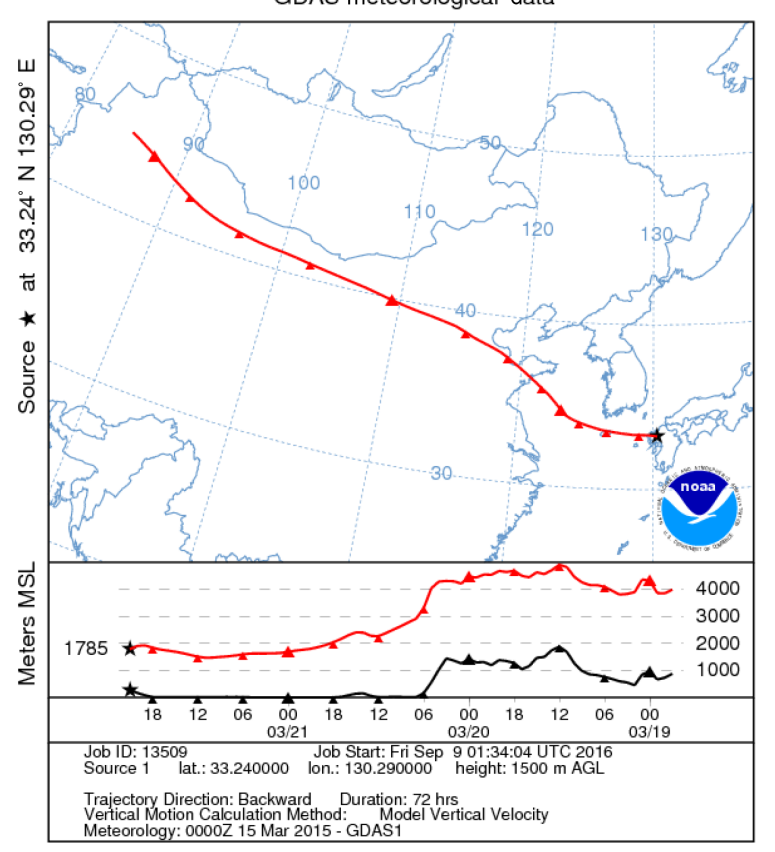

(b)

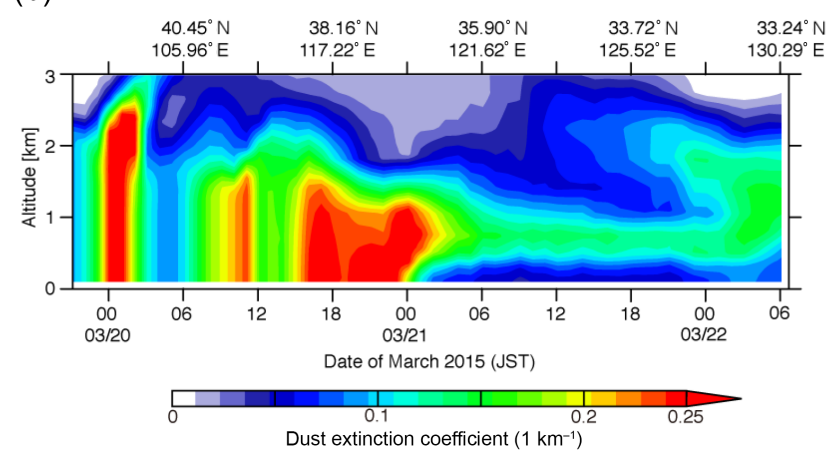

Figure 8. (a) The $72 \mathrm{~h}$ HYSPLIT-model backward trajectory (red line) and terrain height (black line) from Saga at $1500 \mathrm{~m}$ above ground level (a.g.1.) ending at 06:00 JST on 22 May 2015. (b) Timealtitude cross section of dust extinction coefficient simulated by the MASINGAR mk-2 along the trajectory path.

dust extinction coefficients to total aerosol extinction coefficients simulated by MASINGAR-mk2 with potential temperatures over Saga for 20-31 March 2015. For the event on 22 March, the model predicted dust particles (about 60$100 \%)$ in the altitude range $1-3 \mathrm{~km}$, and it predicted sulfate (about 40-60\%) and dust (about 30-40\%) particles below $1 \mathrm{~km}$. The numbers in parentheses indicate the ratio of each component's extinction coefficient to the total extinction coefficient. The dust particles descended to the surface in the afternoon (Fig. 7b). For the event on 30 March, MASINGAR mk-2 predicted dust particles (about 50-100\%) at altitudes of 1-6 km, and it predicted sulfate (about 50-80\%) and dust (about $0-20 \%$ ) particles below $1 \mathrm{~km}$ in the morning. Mie (a) NOAA HYSPLIT MODEL Backward trajectory ending at 21:00 UTC 21 Mar 15 GDAS meteorological data

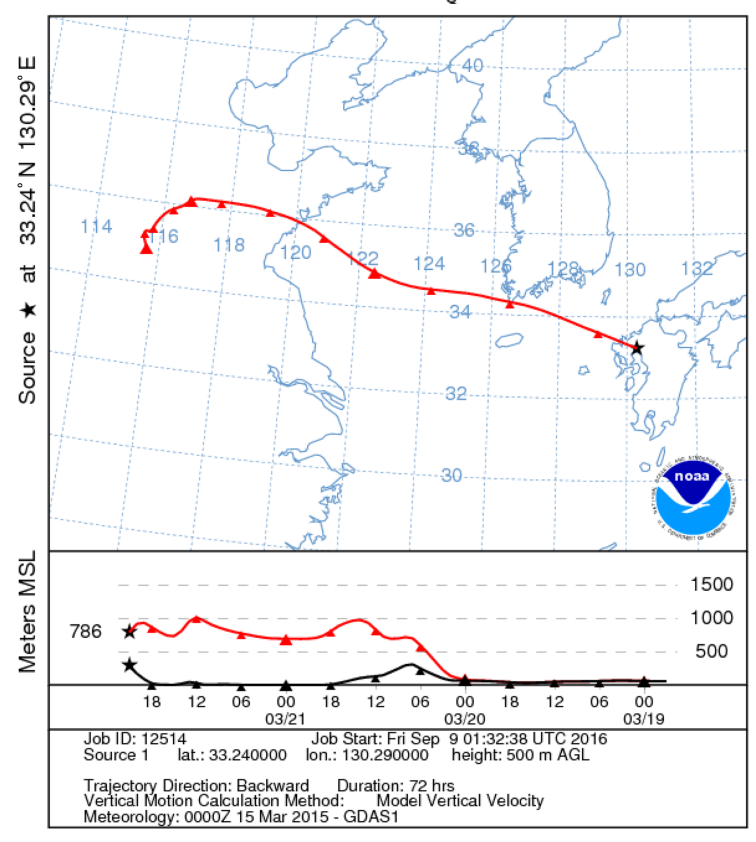

(b)

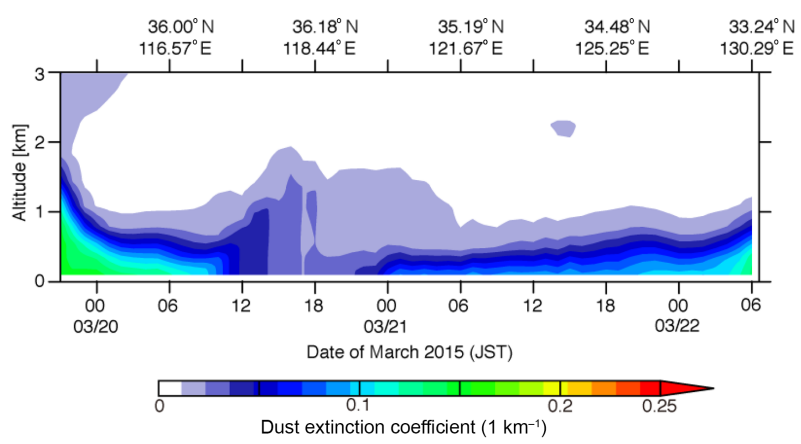

Figure 9. Same as Fig. 8, but for $500 \mathrm{~m}$ a.g.1.

lidar data supported the model prediction because $D_{\mathrm{p}}$ was high $(17 \pm 6 \%)$ at altitudes of $1-3 \mathrm{~km}$ and low $(10 \pm 3 \%)$ below $1 \mathrm{~km}$. For both events, small amounts of organic carbon, black carbon, and sea salt particles were predicted.

To identify the origin of the aerosols and related transport processes, three-dimensional backward trajectories of air parcels were calculated with the NOAA Hybrid Single Particle Lagrangian Integrated Trajectory (HYSPRIT) model (Draxler and Hess, 1998; Stein et al., 2015). Air parcels were initially left at altitudes of $1500 \mathrm{~m}$ (Fig. 8a) and $500 \mathrm{~m}$ (Fig. 9a) over the lidar site at Saga. The trajectories were calculated for 3 days from 21:00 UTC on 21 (06:00 JST on 22) March 2015. Figures $8 b$ and $9 b$ show the time-altitude cross sections of dust and sulfate extinction coefficients simulated by MASINGAR mk-2 along the trajectory paths of Figs. 8a and 9a, respectively. Based on the results of the backward trajectories and the model simulations, the dust 
(a)

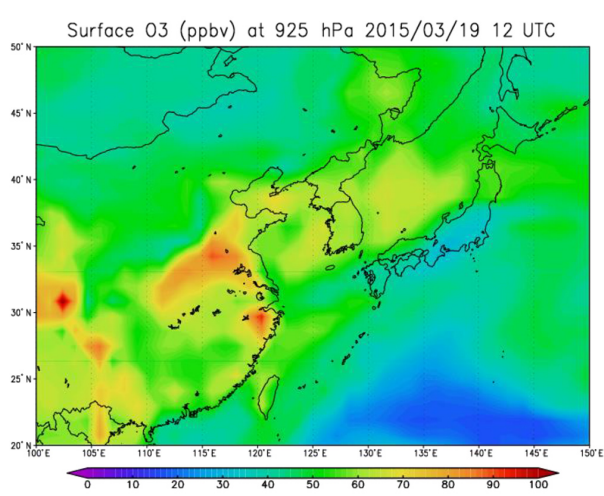

(c)

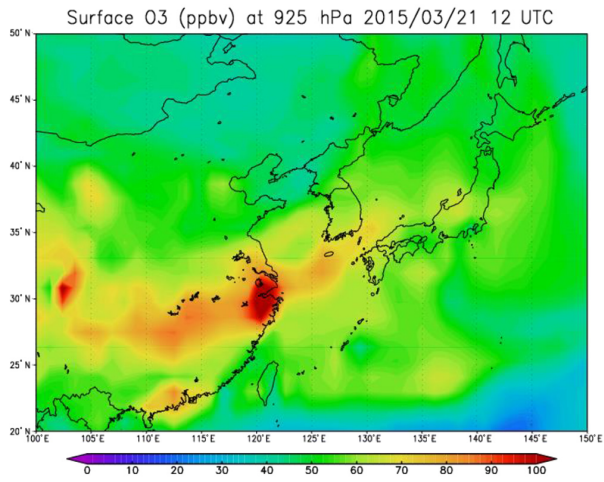

(b)

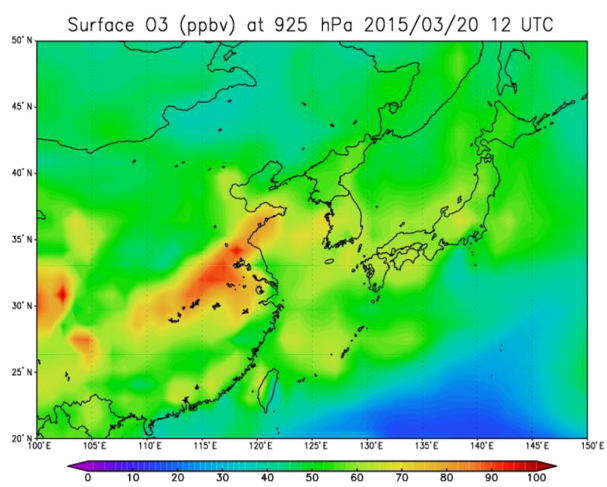

(d)

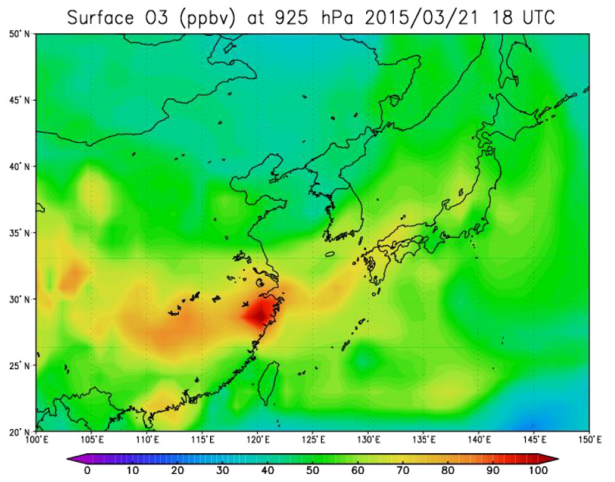

Figure 10. Horizontal maps of ozone volume mixing ratios in ppbv predicted by MRI-CCM2 for the $925 \mathrm{hPa}$ pressure level (an altitude of about $760 \mathrm{~m}$ ) at 21:00 JST (JST = UT + 9) on (a) 19, (b) 20 and (c) 21 March and (d) at 03:00 JST on 22 March 2015.

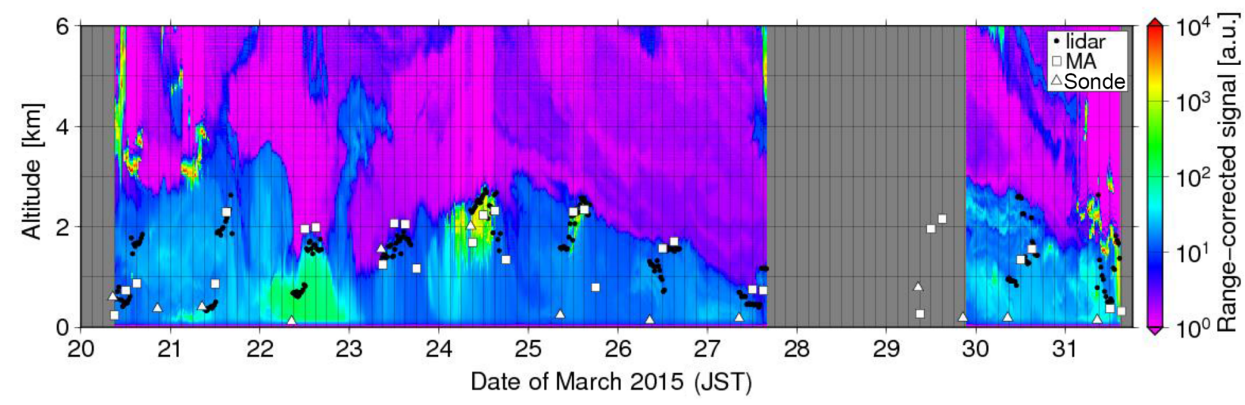

Figure 11. Time-altitude cross section of range-corrected backscatter signal at $1064 \mathrm{~nm}$ (color shading) and the heights of the mixed layers estimated by Mie lidar (black circles), radiosonde (white triangles), and JMA Meso-Scale Meteorological Analysis (white squares) data over Saga from 09:24 JST on 20 March to 14:34 JST on 31 March 2015.

and sulfate particles on 22 March could have been transported within about 2 days from the Gobi Desert and the North China Plain (NCP), respectively, to the measurement site. The MASINGAR mk-2 simulation suggested that the dust particles emitted during 18:00-24:00 UTC on 19 March around $40^{\circ} \mathrm{N}$ and $105^{\circ} \mathrm{E}$ were responsible for the dust storm captured by the Mie lidar observation. The highest concentrations of $\mathrm{SO}_{2}$ and $\mathrm{NO}_{2}$ in the world were observed in the NCP during 2013-2015 by OMI onboard NASA's Aura satellite, based on Fig. 5 of Krotkov et al. (2016). These gases are important precursors of sulfate particles and ozone. Figure 10 shows horizontal maps of ozone volume mixing ratios at $925 \mathrm{hPa}$ (an altitude of about $760 \mathrm{~m}$ ) simulated by MRI-CCM2 at 21:00 JST on 19, 20, and 21 March and at 03:00 JST on 22 March 2015. These maps indicate that the high ozone concentrations could have been transported from 
the NCP to the Yellow Sea and then to Saga within about 2 days.

Because it was difficult to obtain observational data of surface ozone and sulfate particles over the NCP, including Beijing, on 19-20 March, we referred to the following papers with respect to those data. According to the ozonesonde measurements made by Wang et al. (2012), ozone concentrations $\geq 90 \mathrm{ppbv}$ were observed over Beijing, China, in late March. Ma et al. (2016) reported a significant increase in surface ozone from 2003 to 2015 at Shangdianzi $\left(40.65^{\circ} \mathrm{N}\right.$, $117.10^{\circ} \mathrm{E}$ ), which is located about $100 \mathrm{~km}$ northeast of suburban Beijing, and the maximum daily average $8 \mathrm{~h}$ concentrations of ozone appear to have been $>100 \mathrm{ppbv}$ in March 2015 based on Fig. 2 in their paper. High PM $_{2.5}$ and submicron aerosol concentrations have been observed in Beijing (Zhang et al., 2013; Sun et al., 2015). Ozone and aerosol concentrations may therefore have been high in March 2015 over the NCP.

To elucidate the vertical transport processes of the aerosol and ozone in the lower troposphere over the measurement site, we show in Fig. 11 the time variations of the heights of the mixed layers from 2 hours after sunrise to 2 hours before sunset during 09:24 JST on 20 March through 14:34 JST on 31 March 2015. These altitudes were estimated from (1) the $1064 \mathrm{~nm}$ range-corrected backscatter signals, with a range resolution of $15 \mathrm{~m}$ and a time interval of $20 \mathrm{~min}$, using the wavelet covariance transform method (Baars et al., 2008; Izumi et al., 2017), and (2) signals obtained from radiosonde data at Fukuoka and the JMA mesoscale analysis (MA) data over Saga using the parcel method (Holzworth, 1964). When the mixed layers developed in the afternoon, the heights of the mixed layers (1.5-2 km) estimated by Mie lidar were similar to those estimated by MA. Although the radiosonde data at 09:00 JST on 22 March found the height of the mixed layer to be $117 \mathrm{~m}$ (Stull, 1988), it was difficult for Mie lidar to detect the mixed layer because the lowest altitude of the Mie lidar measurement was $225 \mathrm{~m}$.

The dust particles that originated from the Gobi Desert arrived at altitudes of $1-3 \mathrm{~km}$ over the lidar site at 06:00 JST on 22 March. When the mixed layer developed to $1.5-2 \mathrm{~km}$ at 11:00-15:00 JST on 22, the dust particles were assumed to be mixed into the boundary layer and then to reach the surface by entrainment, as simulated in Fig. 7b. This may explain the sharp increase in $\mathrm{PM}_{2.5}$ concentrations at the surface after 11:00 JST, as shown in Fig. 4. A similar phenomenon was observed over the northern Kyushu area during the dust event in late May-early June 2014 (Uno et al., 2016). A similar highsurface-ozone event was observed by eight ozonesonde measurements during 6-9 June 2003 over the Seoul metropolitan region (Oh et al., 2010).

\section{Concluding remarks}

By using ozone DIAL and a two-wavelength polarization (Mie) lidar, we made continuous measurements of ozone and aerosol concentrations over Saga during 20-31 March 2015. High ozone and high aerosol concentrations that occurred nearly simultaneously were observed in the altitude range 0.5-1.5 km from 03:00 to 20:00 JST on 22 March 2015. The ozone volume mixing ratio was larger than $100 \mathrm{ppbv}$. The aerosol extinction coefficient and AOD at $532 \mathrm{~nm}$ were larger than $0.5 \mathrm{~km}^{-1}$ and 1.5 , respectively.

Backward trajectory analysis and the simulations by the MASINGAR mk-2 and MRI-CCM2 models indicated that mineral dust particles from the Gobi Desert and an air mass with high ozone and aerosol (mainly sulfate) concentrations that originated from the North China Plain could have been transported over the lidar site within about 2 days. Based on the lidar and surface measurement data and the simulation by the MASINGAR-mk2, there is a possibility that the air mass with high ozone and aerosol concentrations could have been transported from the lower troposphere to the surface by vertical mixing when the planetary boundary layer developed in the afternoon of 22 March 2015. The combination of ozone DIAL measurements with surface in situ ozone measurements is very useful for studying the process of descent of high ozone concentrations in the lower troposphere to the surface and the impacts on surface air quality. Such measurements of pollution plumes that descend from the free troposphere to the surface are highly recommended (HTAP, 2010).

MRI-CCM2 could approximately reproduce the highozone volume mixing ratios after some modifications of physical and chemical parameters. MASINGAR mk-2 successfully predicted high-aerosol-concentration events, but the predicted peak AOD was about one-third of the observed AOD. For further improvement of these models, it will be important to continue comparing these models with ozone DIAL, Mie lidar, and surface in situ ozone and particle measurements.

\section{Data availability}

The reference and website for the data we used in the paper are provided in the text. The lidar and simulation data presented in the paper are available from the authors upon request (uchino.osamu@nies.go.jp).

Competing interests. The authors declare that they have no conflict of interest.

Acknowledgements. We used radiosonde data measured by the Japan Meteorological Agency and hourly concentrations of surface oxidant and $\mathrm{PM}_{2.5}$ measured by the Saga Prefectural Environmental Research Center. The NOAA Hybrid Single Particle 
Lagrangian Integrated Trajectory (HYSPRIT) model was used to calculate backward trajectories of air parcels. The authors thank the anonymous referees and editors for helpful comments and suggestions.

Edited by: Y. Kanaya

Reviewed by: two anonymous referees

\section{References}

Akimoto, H., Mukai, H., Nishikawa, M., Murano, K., Hatakeyama, S., Liu, C., Buhr, M., Hsu, K. J., Jaffe, D. A., Zhang, L., Honrath, R., Merrill, J. T., and Newell, R. E.: Long-range transport of ozone in the East Asian Pacific rim region, J. Geophys. Res., 101, 1999-2010, 1996.

Ancellet, G. and Ravetta, F.: Analysis and validation of ozone variability observed by lidar during the ESCOMPTE-2001 campaign, Atmos. Res., 74, 435-459, 2005.

Anderson, T. L., Masonis, S. J., Covert, D. S., Ahlquist, N. C., Howell, S. G., Clarke, A. D., and McNaughton, C. S.: Variability of aerosol optical properties derived from in situ aircraft measurements during ACE-Asia, J. Geophys. Res., 108, 8647, doi:10.1029/2002JD003247, 2003.

Baars, H., Ansmann, A., Engelmann, R., and Althausen, D.: Continuous monitoring of the boundary-layer top with lidar, Atmos. Chem. Phys., 8, 7281-7296, doi:10.5194/acp-8-7281-2008, 2008.

Bak, J., Kim, J. H., Liu, X., Chance, K., and Kim, J.: Evaluation of ozone profile and tropospheric ozone retrievals from GEMS and OMI spectra, Atmos. Meas. Tech., 6, 239-249, doi:10.5194/amt6-239-2013, 2013.

Banta, R. M., Senff, C. J., White, A. B., Trainer, M., McNider, R. T., Valente, R. J., Mayor, S. D., Alvarez, R. J., Hardesty, R. M., Parrish, D., and Fesenfeld, F. C.: Daytime buildup and nighttime transport of urban ozone in the boundary layer during a stagnation episode, J. Geophys. Res., 103, 22519-22544, 1998.

Carslaw, D. C.: Evidence of an increasing $\mathrm{NO}_{2} / \mathrm{NO}_{x}$ emissions ratio from road traffic emissions, Atmos. Environ., 39, 4793-4802, 2005.

Cattrall, C., Reagan, J., Thome, K., and Dubovik, O.: Variability of aerosol and spectral lidar and backscatter and extinction ratios of key aerosol types derived from selected Aerosol Robotic Network locations, J. Geophys. Res., 110, D10S11, doi:10.1029/2004JD005124, 2005.

Deushi, M. and Shibata, K.: Development of a Meteorological Research Institute Chemistry-Climate Model version 2 for the study of tropospheric and stratospheric chemistry, Pap. Meteorol. Geophys., 62, 1-46, doi:10.2467/mripapers.62.1, 2011.

Draxler, R. R. and Hess, G. D.: An overview of the HYSPLIT_4 modeling system for trajectories, dispersion, and deposition, Aust. Meteor. Mag., 47, 295-308, 1998.

Eisele, H. and Trickl, T.: Improvements of the aerosol algorithm in ozone lidar data processing by use of evolutionary strategies, Appl. Optics, 44, 2638-2651, 2005.

Fernald, F. G.: Analysis of atmospheric lidar observations: some comments, Appl. Optics, 23, 652-653, 1984.

Granier, C., Bessagnet, B., Bond, T., D’Angiola, A., van der Gon, H. D.., Frost, G. J., Heil, A., Kaiser, J. W., Kinne, S., Klimont,
Z., Kloster, S., Lamarque, J. -F., Liousse, C., Masui, T., Meleux, F., Mieville, A., Ohara, T., Raut, J.-C., Riahi, K., Schultz, M. G., Smith, S. J., Thompson, A., van Aardenne, J., van der Werf, G. R., and van Vuuren, D. P.: Evolution of anthropogenic and biomass burning emission of air pollutants at global and regional scales during the 1980-2010 period, Climate Change, 109, 163190, 2011.

Hara, Y., Yumimoto, K., Uno, I., Shimizu, A., Sugimoto, N., Liu, Z., and Winker, D. M.: Asian dust outflow in the PBL and free atmosphere retrieved by NASA CALIPSO and an assimilated dust transport model, Atmos. Chem. Phys., 9, 1227-1239, doi:10.5194/acp-9-1227-2009, 2009.

Hemispheric Transport of Air Pollution (HTAP) 2010, Part A: Ozone and particulate matter, edited by: Dentener, F., Keating, T., and Akimoto, H., Air Pollution Studies No. 17, United Nations, New York and Geneva, 278 pp., 2010.

Holzworth, G. C.: Estimates of mean maximum mixing depths in the contiguous United States, Mon. Weather Rev., 92, 235-242, 1964.

Houweling, S., Hartmann, W., Aben, I., Schrijver, H., Skidmore, J., Roelofs, G.-J., and Breon, F.-M.: Evidence of systematic errors in SCIAMACHY-observed $\mathrm{CO}_{2}$ due to aerosols, Atmos. Chem. Phys., 5, 3003-3013, doi:10.5194/acp-5-3003-2005, 2005.

Intergovernmental Panel on Climate Change (IPCC): Climate Change 2013: The Physical Science Basis: Contribution of Working Group I to the Fifth Assessment Report of the Intergovernmental Panel on Climate Change, edited by: Stocker, T. F., Qin, D., Plattner, G.-K., Tignor, M., Allen, S. K., Boschung, J., Nauels, A., Xia, Y., Bex, V., and Midgley, P. M., Cambridge University Press, Cambridge, United Kingdom and New York, NY, USA, 1535 pp., doi:10.1017/CBO9781107415324, 2013.

Iwasaka, Y., Yamato, M., Imasu, R., and Ono, A.: Transport of Asian dust (KOSA) particles; importance of weak KOSA events on the geochemical cycle of soil particles, Tellus, 40B, 494-503, 1988.

Izumi, T., Uchino, O., Sakai, T., Nagai, T., and Morino, I.: Mixed layer height calculated from Mie lidar data, Tenki, submitted, 2017 (in Japanese).

Kobayashi, E., Uchiyama, A., Yamazaki, A., and Matsuse, K: Application of the maximum likelihood method to the inversion algorithm for analyzing aerosol optical properties from sun and sky radiance measurements, J. Meteor. Soc. Jpn., 84, 1047-1062, 2006.

Kourtidis, K., Zerefos, C., Rapsomanikis, S., Simeonov, V., Balis, D., Perros, P. E., Thompson, A. M., Witte, J., Calpini, B., Sharobiem, W. M., Papayannis, A., Mihalopoulos, N., and Drakou, R.: Regional levels of ozone in the troposphere over eastern Mediterranean, J. Geophys. Res., 107, 8140, doi:10.1029/2000JD000140, 2002.

Krotkov, N. A., McLinden, C. A., Li, C., Lamsal, L. N., Celarier, E. A., Marchenko, S. V., Swartz, W. H., Bucsela, E. J., Joiner, J., Duncan, B. N., Boersma, K. F., Veefkind, J. P., Levelt, P. F., Fioletov, V. E., Dickerson, R. R., He, H., Lu, Z., and Streets, D. G.: Aura OMI observations of regional $\mathrm{SO}_{2}$ and $\mathrm{NO}_{2}$ pollution changes from 2005 to 2015, Atmos. Chem. Phys., 16, 46054629, doi:10.5194/acp-16-4605-2016, 2016.

Kuang, S., Newchurch, M. J., Burris, J., Wang, L., Buckley, P. I., Johnson, S., Knupp, K., Huang, G., Phillips, D., and Cantrell, W.: 
Nocturnal ozone enhancement in the lower troposphere observed by lidar, Atmos. Environ., 45, 6078-6084, 2011.

Kurokawa, J., Ohara, T., Morikawa, T., Hanayama, S., JanssensMaenhout, G., Fukui, T., Kawashima, K., and Akimoto, H.: Emissions of air pollutants and greenhouse gases over Asian regions during 2000-2008: Regional Emission inventory in ASia (REAS) version 2, Atmos. Chem. Phys., 13, 11019-11058, doi:10.5194/acp-13-11019-2013, 2013.

Ma, Z., Xu, J., Quan, W., Zhang, Z., Lin, W., and Xu, X.: Significant increase of surface ozone at a rural site, north of eastern China, Atmos. Chem. Phys., 16, 3969-3977, doi:10.5194/acp-16-39692016, 2016.

Murayama, T., Sugimoto, N., Uno, I., Kinoshita, K., Aoki, K., Hagiwara. N., Liu, Z., Matsui, I., Sakai, T., Shibata, T., Arao, K., Sohn, B. J., Won, J. G., Yoon, S. C., Li, T., Zhou, J., Hu, H., Abo, M., Iokibe, K., Koga, R., and Iwasaka, Y.: Ground-based network observation of Asian dust events of April 1998 in east Asia, J. Geophys. Res., 106, 18345-18359, 2001.

Nakazato, M., Nagai, T., Sakai, T., and Hirose, Y.: Tropospheric ozone differential-absorption lidar using stimulated Raman scattering in carbon dioxide, Appl. Optics, 46, 2269-2279, 2007.

Oh, I.-B., Kim, Y.-K., Hwang, M.-K., Kim, C.-H., Kim, S., and Song, S.-K.: Elevated ozone layers over the Seoul metropolitan region in Korea: evidence for long-range ozone transport from eastern China and its contribution to surface concentrations, J. Appl. Meteor. Clim., 49, 203-220, doi:10.1175/2009JAMC2213.1, 2010.

Ohara, T., Akimoto, H., Kurokawa, J., Horii, N., Yamaji, K., Yan, X., and Hayasaka, T.: An Asian emission inventory of anthropogenic emission sources for the period 1980-2020, Atmos. Chem. Phys., 7, 4419-4444, doi:10.5194/acp-7-4419-2007, 2007.

Ohyama, H., Kawakami, S., Shiomi, K., and Miyagawa, K.: Retrievals of total and tropospheric ozone from GOSAT thermal infrared spectral radiances, IEEE T. Geosci. Remote, 50, 17701784, doi:10.1109/TGRS.2001.2170178, 2012.

Sakai, T., Nagai, T., Nakazato, M., Mano, Y., and Matsumura, T.: Ice clouds and Asian dust studied with lidar measurements of particle extinction-to-backscatter ratio, particle depolarization, and water-vapor mixing ratio over Tsukuba, Appl. Optics, 42, 7103-7116, 2003.

Stein, A. F., Draxler, R. R., Rolph, G. D., Stunder, B. J. B., Cohen, M. D., and Ngan, F.: NOAA's HYSPLIT atmospheric transport and dispersion modeling system, B. Am. Meteorol. Soc., 96, 2059-2077, 2015.

Stull, R. B.: An introduction to boundary layer meteorology, Klumer Academic Publications, 670 pp., 1988.

Sun, Y. L., Wang, Z. F., Du, W., Zhang, Q., Wang, Q. Q., Fu, P. Q., Pan, X. L., Li, J., Jayne, J., and Worsnop, D. R.: Longterm real-time measurements of aerosol particle composition in Beijing, China: seasonal variations, meteorological effects, and source analysis, Atmos. Chem. Phys., 15, 10149-10165, doi:10.5194/acp-15-10149-2015, 2015.

Tanaka, T. Y., Orito, K., Sekiyama, T. T., Shibata, K., Chiba, M., and Tanaka, H.: MASINGAR, a global tropospheric aerosol chemical transport model coupled with MRI/JMA98 GCM: Model description, Pap. Meteor. Geophys., 53, 119-138, 2003.
Uchino, O. and Tabata, I.: Mobile lidar for simultaneous measurements of ozone, aerosols, and temperature in the stratosphere, Appl. Optics, 30, 2005-2012, 1991.

Uchino, O., Kikuchi, N., Sakai, T., Morino, I., Yoshida, Y., Nagai, T., Shimizu, A., Shibata, T., Yamazaki, A., Uchiyama, A., Kikuchi, N., Oshchepkov, S., Bril, A., and Yokota, T.: Influence of aerosols and thin cirrus clouds on the GOSAT-observed $\mathrm{CO}_{2}$ : a case study over Tsukuba, Atmos. Chem. Phys., 12, 3393-3404, doi:10.5194/acp-12-3393-2012, 2012a.

Uchino, O., Sakai, T., Nagai, T., Nakamae, K., Morino, I., Arai, K., Okumura, H., Takubo, S., Kawasaki, T., Mano, Y., Matsunaga, T., and Yokota, T.: On recent (2008-2012) stratospheric aerosols observed by lidar over Japan, Atmos. Chem. Phys., 12, 1197511984, doi:10.5194/acp-12-11975-2012, 2012 b.

Uchino, O., Sakai, T., Nagai, T., Morino, I., Maki, T., Deushi, M., Shibata, K., Kajino, M., Kawasaki, T., Akaho, T., Takubo, S., Okumura, H., Arai, K., Nakazato, M., Matsunaga, T., Yokota, T., Kawakami, S., Kita, K., and Sasano, Y.: DIAL measurement of lower tropospheric ozone over Saga $\left(33.24^{\circ} \mathrm{N}, 130.29^{\circ} \mathrm{E}\right)$, Japan, and comparison with a chemistry-climate model, Atmos. Meas. Tech., 7, 1385-1394, doi:10.5194/amt-7-1385-2014, 2014.

Uno, I., Wang, Z., Chiba, M., Chun, Y. S., Gong, S. L., Hara, Y., Jung, E., Lee, S.-S., Liu, M., Mikami, M., Music, S., Nickovic, S., Satake, S., Shao, Y., Song, Z., Sugimoto, N., Tanaka, T., and Westphal, D. L.: Dust model intercomparison (DMIP) study over Asia: Overview, J. Geophys. Res., 111, D12213, doi:10.1029/2005JD006575, 2006.

Uno, I., Pan, X., Itahashi, S., Yumimoto, K., Hara, Y., Kuribayashi, M., Yamamoto, S., Shimohara, T., Tamura, K., Ogata, Y., Osada, K., Kamikuchi, Y., Yamada, S., and Kobayashi, H.: Overview of long-range yellow sand and high concentration of air pollution observed over the northern Kyusyu area in late May-early June 2014, J. Jpn. Soc. Atmos. Environ., 51, 44-57, 2016.

Veefkind, J. P., Aben, I., McMullan, K., Förster, H., de Vries, J., Otter, G., Claas, J., Eskes, H. J., de Haan, J. F., Kleipool, Q., van Weele, M., Hasekamp, O., Hoogeveen, R., Landgraf, J., Snel, R., Tol, P., Ingmann, P., Voors, R., Kruizinga, B., Vink, R., Visser, H., and Levelt, P. F.: TROPOMI on the ESA Sentinel-5 Precursor: A GMES mission for global observations of the atmospheric composition for climate, air quality and ozone layer applications, Remote Sens. Environ., 120, 70-83, 2012.

Wang, Y., Konopka, P., Liu, Y., Chen, H., Müller, R., Plöger, F., Riese, M., Cai, Z., and Lü, D.: Tropospheric ozone trend over Beijing from 2002-2010: ozonesonde measurements and modeling analysis, Atmos. Chem. Phys., 12, 8389-8399, doi:10.5194/acp-12-8389-2012, 2012.

Yamaji, K., T. Ohara, T., Uno, I., Tanimoto, H., Kurokawa, J., and Akimoto, H.: Analysis of the seasonal variation of ozone in the boundary layer in East Asia using the Community Multiscale Air Quality model: What controls surface ozone levels over Japan?, Atmos. Environ., 40, 1856-1868, 2006.

Yue, $X$. and Unger, N.: Ozone vegetation damage effects on gross primary productivity in the United States, Atmos. Chem. Phys., 14, 9137-9153, doi:10.5194/acp-14-9137-2014, 2014.

Yukimoto, S., Adachi, Y., Hosaka, M., Sakami, T., Yoshimura, H., Hirabara, M., Tanaka, T. Y., Shindo, E., Tsujino, H., Deushi, M., Mizuta, R., Yabu, S., Obata, A., Nakano, H., Koshiro, T., Ose, T., and Kitoh, A.: A new global climate model of the Me- 
teorological Research Institute: MRI-CGCM3 Model Description and Basic Performance, J. Meterol. Soc. Jpn., 90A, 23-64, doi:10.2151/jmsj.2012-A02, 2012.

Yumimoto, K., Nagao, T. M., Kikuchi, M., Sekiyama, T. T., Murakami, H., Tanaka, T. Y., Ogi, A., Irie, H., Khatari, P., Okumura, H., Arai, K., Morino, I., Uchino, O., and Maki, T.: Aerosol data assimilation using data from Himawari-8, a next-generation geostationary meteorological satellite, Geophys. Res. Lett., 43, 5886-5894, doi:10.1002/2016GL069298, 2016.
Zhang, R., Jing, J., Tao, J., Hsu, S.-C., Wang, G., Cao, J., Lee, C. S. L., Zhu, L., Chen, Z., Zhao, Y., and Shen, Z.: Chemical characterization and source apportionment of $\mathrm{PM}_{2.5}$ in Beijing: seasonal perspective, Atmos. Chem. Phys., 13, 7053-7074, doi:10.5194/acp-13-7053-2013, 2013. 